\title{
Segmentasi Citra Berwarna dengan Menggunakan Metode Clustering Berbasis Patch untuk Identifikasi Mycobacterium Tuberculosis
}

\author{
Riries Rulaningtyas ${ }^{1}$, Andriyan B. Suksmono ${ }^{2}$, Tati L. R. Mengko ${ }^{3}$, G. A. Putri Saptawati ${ }^{4}$ \\ ${ }^{1}$ Departemen Fisika, Universitas Airlangga Surabaya \\ ${ }^{2,3,4}$ Sekolah Teknik Elektro dan Informatika, Institut Teknologi Bandung
}

Email : riries-r@fst.unair.ac.id

\begin{abstract}
Abstrak
Citra berwarna memiliki banyak variasi nilai intensitas pada masing-masing piksel dalam satu citra. Dengan kasat mata, citra seperti terlihat memiliki warna yang sama dengan citra yang lain. Namun bila diolah oleh komputer suatu piksel dengan warna yang sama dengan piksel yang lain, ternyata memiliki kombinasi nilai intensitas yang berbeda. Variasi nilai intensitas ini akan sangat mempengaruhi hasil proses pengolahan citra oleh komputer.

Dalam penelitian ini, dilakukan uji coba proses segmentasi citra berwarna pada citra mikroskopis bakteri TBC (mycobacterium tuberculosis) yang berasal dari dahak atau sputum pasien, sebagai sampel citra warna yang memiliki variasi nilai intensitas yang begitu kompleks. Sputum yang diperoleh dari pasien dilakukan pewarnaan dengan metode pewarnaan Ziehl - Neelsen. Metode pewarnaan ini umum digunakan di puskesmas, karena di puskesmas pada umumnya menggunakan mikroskop optik untuk memeriksa slide sputum. Hasil pewarnaan memberikan efek warna merah untuk bakteri TB dan background berwarna biru. Hasil pewarnaan ini memberikan citra slide yang kompleks, akibat hasil pewarnaan yang berbeda bergantung pada skill tenaga laboran, sehingga petugas klinis mengalami kesulitan ketika melakukan pemeriksaan slide secara manual. Untuk membantu petugas klinis dalam melakukan pembacaan slide, maka pada penelitian ini dilakukan segmentasi warna citra slide untuk mengekstrasi citra bakteri TB dan menghilangkan citra background.

Beberapa metode telah dilakukan dalam penelitian ini, yaitu adaptive color thresholding pada ruang warna RGB, HSV, CIE L*a*b, yang memberikan hasil segmentasi yang baik pada ruang warna CIE L*a*b. Kemudian dicoba metode segmentasi k-means clustering dan k-nearest neighbors untuk memperbaiki performansi segmentasi warna adaptive color thresholding, dan metode $k$-nearest neighbors memberikan akurasi yang paling baik $97,90 \%$, namun belum mampu memberikan hasil yang bagus pada citra utuh dan waktu komputasi proses pembelajaran yang lama.

Untuk memperbaiki performansi hasil segmentasi citra berwarna pada citra sputum penyakit TBC ini, maka pada penelitian ini dilakukan metode segmentasi fast k-means clustering, yang membutuhkan waktu komputasi yang lebih cepat dari metode $k$-nearest neihgbors dan hasil segmentasi yang lebih baik. Metode fast $k$-means clustering yang digunakan ditunjang dengan penerapan pengolahan citra berbasis patch, untuk menghindari variasi global yang dapat mempengaruhi hasil segmentasi. Dengan metode segmentasi citra berbasis patch ini ternyata memberikan hasil yang lebih baik dibanding metode segmentasi yang diterapkan pada citra utuh yang secara serentak dilakukan pengolahan citranya.
\end{abstract}

Kata kunci : Segementasi warna, color thresholding, $k$-means clustering, $k$-nearest neighbors, patch.

\section{PENDAHULUAN}

Citra berwarna memiliki banyak sekali informasi yang terkandung di dalamnya. Namun selama ini, pengolahan citra lebih banyak menggunakan citra grayscale dari pada mengolah secara langsung citra berwarna. Pengubahan citra berwarna menjadi citra grayscale dapat menyebabkan hilangnya beberapa informasi yang terdapat pada citra berwarna.

Citra berwarna terdiri lebih dari satu kanal warna yang masing - masing memiliki vektor warna yang berbeda. Disamping itu citra berwarna juga memiliki sifat yang multi varian. Akibat pengaruh pencahayaan yang berbeda ataupun penskalaan pada citra yang berbeda juga ikut mempengaruhi sifat multi varian dari citra berwarna.

Warna pada citra memiliki range skala yang berbeda satu sama lain, walaupun dengan kasat mata memiliki persepsi warna yang sama. Kombinasi intensitas citra antarkanal yang berbeda, juga menghasilkan variasi warna yang berbeda. Variasi nilai intensitas pada citra ini dapat dikenali oleh komputer saat menerapkan metode pengolahan citra. Variasi nilai intensitas ini sangat berpengaruh pada hasil pengolahan citra, terutama pada aplikasi pengenalan objek berdasarkan warna.

Pada penelitian ini mencoba teknik segmentasi citra berwarna dengan menggunakan metode clustering yang dikombinasikan dengan teknik patch untuk menghasilkan 
performansi hasil segmentasi yang bagus dan akurat sesuai dengan yang diinginkan untuk dilakukan pengolahan lebih lanjut. Dalam sistem pengenalan pola, hasil segmentasi yang baik dan akurat akan dapat meringankan proses tersebut. Sebagai sampel yang digunakan untuk menerapkan metode clustering berbasis patch, dalam penelitian ini digunakan citra berwarna dari sputum penderita penyakit tuberkulosis paru (TBC). Citra sputum mikroskpis penyakit tuberkulosis, sangat bersifat multi varian. Hal ini dikarenakan teknik pewarnaan sampel yang belum standard dan tergantung dari skill tenaga laboran yang melakukannya.

Pewarnaan Ziehl-Neelsen akan memberikan warna merah jambu terhadap bakteri tuberkulosis (TB), sedangkan background yang berupa dahak akan memberikan warna biru muda. Pemeriksaan dahak (sputum) melalui mikroskop memegang peranan penting pada diagnosis penyakit TBC. Pasien yang memiliki gejala akan penyakit TBC terlebih dahulu melalui tahapan pemeriksaan dahak.

Penelitian mengenai segmentasi citra berwarna sputum penyakit TBC yang telah dilakukan yaitu penelitian (M.K. Osman, 2010). Dalam penelitian tersebut dilakukan segmentasi dengan menggunakan metode K-Means Clustering, namun hasil tersebut masih kurang bagus hasilnya, sehingga dilakukan proses lanjutan yaitu menggunakan teknik median filter dan region growing. Penelitian lain yaitu (M.K. Osman et.al, 2011) menggunakan metode Global Thresholding, K-Means Clustering, Automatic Seeded Region Growing, Local Adaptive Thresholding, dan Median Filter, namun dalam penelitian (M.K. Osman et.al, 2011) memberikan hasil yang belum maksimal yaitu sensitivitas $81.44 \%$ dan beberapa citra background yang tidak diinginkan masih terlihat pada citra hasil segmentasi. Dalam penelitian ini berhasil memperbaiki performansi penelitian (M.K. Osman, 2011), dengan menggunakan metode K-Means Clustering berbasis patch memberikan hasil yang lebih baik tanpa adanya proses lanjutan.

\section{MATERI DAN METODE PENELITIAN}

Pada penelitian ini, mencoba menganalisis hasil global thresholding (sebagai teknik segmentasi dasar) pada tiga ruang warna yang berbeda yaitu RGB, HSV, dan CIE Lab, kemudian membandingkan hasil segmentasi untuk ketiga ruang warna tersebut, kemudian dipilih satu ruang warna yang optimal untuk dilakukan proses pengolahan segmentasi warna yang lebih akurat lagi.

Citra sputum penderita TBC yang digunakan untuk eksperimen adalah hasil pewarnaan Ziehl-Neelsen. Jumlah preparat sputum yang digunakan sebanyak 46 buah, dengan citra sputum yang diambil melalui kamera webcam yang terpasang pada mikroskop optik sejumlah 1098 buah citra. Perbesaran citra sputum yang digunakan oleh mikroskop adalah 1000 kali.

\section{Ruang Warna RGB}

Ruang warna RGB (Red, Green, Blue) adalah kombinasi warna primer yaitu merah, hijau, dan biru, yang biasa digunakan oleh monitor komputer atau televisi. Warna yang dihasilkan berasal dari kombinasi tiga warna dan masing - masing memiliki nilai 8 bit merah, 8 bit hijau, dan 8 bit biru. Campuran ketiga warna primer tersebut dengan porposi seimbang akan menghasilkan nuansa warna kelabu. Jika ketiga warna ini disaturasikan penuh, maka akan menghasilkan warna putih (Pratt,2007).

\section{Ruang Warna HSV}

Model HSV (Hue, Saturation, Value) menunjukkan ruang warna dalam bentuk tiga komponen utama yaitu hue, saturation, dan value (atau disebut juga brightness). Hue adalah sudut dari 0 sampai 360 derajat. Biasanya 0 adalah merah, 60 derajat adalah kuning, 120 derajat adalah hijau, 180 derajat adalah cyan, 240 derajat adalah biru dan 300 derajat adalah magenta seperti pada Gambar 1. Hue menunjukkan jenis warna (seperti merah, biru, kuning), yaitu tempat warna tersebut ditemukan dalam spectrum warna. Saturasi (saturation) suatu warna adalah ukuran seberapa besar kemurnian dari warna tersebut akibat pengaruh dari warna putih. Seperti warna merah, dengan pengaruh warna putih, warna merh menjadi bervariasi dari warna merah menuju merah muda, yang artinya hue masih tetap bernilai merah tetapi nilai saturasinya berkurang. Komponen HSV berikutnya adalah nilai value atau disebut juga intensitas, yaitu ukuran seberapa besar kecerahan suatu warna atau seberapa besar cahaya datang dari suatu warna. Value memiliki nilai dengan jangkauan 0\% sampai 100\% (Pratt, 2007).

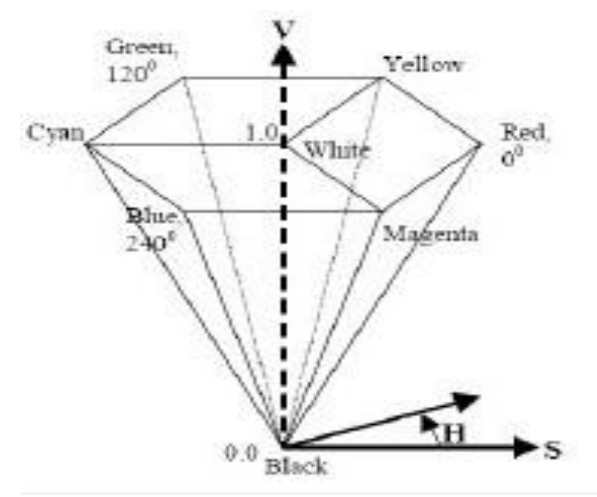

Gambar 1. Nilai Hue, Saturation, dan Value (Pratt,2007 )

Konversi warna RGB ke HSV seperti pada Persamaan 1 sampai dengan 5 (Gonzales, 2008 ).

$$
\begin{gathered}
r=\frac{R}{R+G+B}, \quad g=\frac{G}{R+G+B}, \quad b=\frac{B}{R+G+B} \\
\mathrm{~V}=\max (r, g, b)
\end{gathered}
$$




$$
\begin{aligned}
& H=\quad \begin{array}{cl}
0 & \text { If } S=0 \\
\frac{60 *(q-b)}{s * V} & \text { If } V=r
\end{array} \\
& 60 * 2+\frac{(b-r)}{s * V} \text { If } V=g \\
& 60 * 4+\frac{(r-g)}{s * V} \text { If } V=b \\
& S=\left\{\begin{array}{cl}
0 & \text { if } V=0 \\
V-\frac{\min (r, g, b)}{V} & \text { if } V>0
\end{array}\right. \\
& H=H+360 \quad \text { jika } H<0
\end{aligned}
$$

\section{Ruang Warna $X Y Z$}

Nilai RGB yang terdapat pada suatu piksel dapat ditransformasikan kedalam ruang warna CIE XYZ melaui proses transformasi matriks $3 \times 3$. Transformasi ini melibatkan nilai - nilai tristimulus, yakni suatu pengaturan dari tiga komponen cahaya - linear yang memenuhi fungsi pencocokan warna CIE. Pada ruang warna XYZ, beberapa warna direpresentasikan sebagai nilai yang selalu positif.

Perhitungan untuk transformasi dari ruang warna RGB ke XYZ (dengan nilai referensi putih), adalah melalui perhitungan matriks transformasi seperti pada persamaan berikut ( Pratt, 2007 ) :

$$
\left[\begin{array}{l}
X \\
Y \\
Z
\end{array}\right]=\left[\begin{array}{lll}
0.412453 & 0.357580 & 0.180423 \\
0.212671 & 0.715160 & 0.072169 \\
0.019334 & 0.119193 & 0.950227
\end{array}\right] *\left[\begin{array}{l}
R \\
G \\
B
\end{array}\right]
$$

\section{Ruang Warna $L^{*} a^{*} b^{*}$}

Ruang Warna $\mathrm{L}^{*} \mathrm{a}^{*} \mathrm{~b}^{*}$ atau yang dikenal dengan CIELAB adalah ruang warna yang paling lengkap yang ditetapkan oleh Komisi Internasional tentang iluminasi warna (French Commision Internationale de l'eclairage, dikenal sebagai CIE). Ruang warna ini mampu menggambarkan semua warna yang dapat dilihat dengan mata manusia dan seringkali digunakan sebagai referensi ruang warna.

Perhitungan konversi ruang warna dari XYZ ke $\mathrm{L}^{*} \mathrm{a}^{*} \mathrm{~b}^{*}$ berdasarkan pada persamaan berikut ini (Pratt, 2007 ):

$\mathrm{L}^{*}=116(\mathrm{Y} / \mathrm{Yn})^{1 / 3}-16$, untuk $\mathrm{Y} / \mathrm{Yn}>0.008856$

$\mathrm{L}^{*}=903.3 \mathrm{Y} / \mathrm{Yn} \quad$ selainnya

$a^{*}=500(f(X / X n)-f(Y / Y n))$

$\mathrm{b}^{*}=200(\mathrm{f}(\mathrm{Y} / \mathrm{Yn})-\mathrm{f}(\mathrm{Z} / \mathrm{Zn}))$

$$
\begin{array}{cl}
\text { dimana } f(t)=t^{1 / 3} & \text { untuk } t>0.008856 \\
f(t)=7.787 t+16 / 166 & \text { selainnya }
\end{array}
$$

Terdapat harga delta yang dapat digunakan dalan skala warna CIELAB. $\Delta \mathrm{L}^{*}, \Delta \mathrm{a}^{*}, \Delta \mathrm{b}^{*}$ mengindikasikan seberapa jauh perbedaan standard dan sample antara yang satu dengan lain. Harga delta dapat digunakan sebagai control kualitas atau pengaturan persamaan. Nilai toleransi dapat dintentukan dari harga delta. Jika nilai delta lebih dari nilai toleransi yang diberikan, maka terdapat perbedaan yang jauh antara citra dari objek standard dengan citra sample, sehingga beberapa tipe koreksi dibutuhkan jika nilai delta keluar dari toleransi yang ditetapkan. Sebagai contoh, jika harga $\Delta \mathrm{a}^{*}$ keluar dari toleransi, maka intensitas warna merah atau hijau memerlukan pengaturan kembali. Ketika warna sampel lebih merah atu lebih hijau daripada warna objek standard, hal ini dapat diketahui dari nilai delta. Sebagai contoh, jika $\Delta \mathrm{a}^{*}$ adalah positif, maka warna sampel lebih merah dibandingkan dengan warna objek standard.

Perbedaan warna total $\Delta \mathrm{E}^{*}$ dapat pula ditentukan. $\Delta \mathrm{E}^{*}$ adalah nilai single yang diambil dari perhitungan perbedaan antara nilai $\mathrm{L}^{*}, \mathrm{a}^{*}, \mathrm{~b}^{*}$ dari objek sampel dan objek standard. Akan tetapi jika $\Delta \mathrm{E}^{*}$ keluar dari nilai toleransi, maka bukan berarti parameter $L^{*}, a^{*}, b^{*}$ keluar pula dari toleransi. Dua harga delta lain yang berhubungan dengan skala CIELAB adalah $\Delta C^{*}$ dan $\Delta H^{*} . \Delta C^{*}$ adalah perbedaan dalam warna kromatik antara objek sampel dengan objek standard yang dinyatakan dalam sistem koordinat polar. $\Delta \mathrm{H}^{*}$ adalah perbedaan dalam sudut Hue antara objek sampel dengan objek standard yang dinyatakan pula dalam sistem koordinat polar. CIELAB banyak digunakan pada industri dimana objek memerlukan pengukuran warna, dengan cara membandingkan skala warna standard dengan nilai warna objek sampel. (Hunter Lab, 2008)

\section{Euclidean Distance}

Untuk mengklasifikasikan warna pada suatu kelompok warna tertentu, maka pada hasil penelitian kali ini menggunakan teknik Euclidean Distance, dengan mencari jarak minimum antara dua titik tetangga yang paling berdekatan (nearest neighbor).

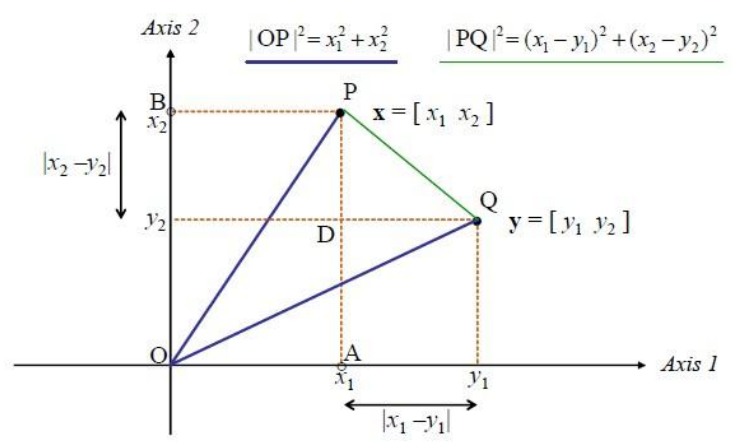

Gambar 2. Teorema Phytagoras untuk dua dimensi (Michael, 2008)

Panjang kuadrat dari vector $\mathrm{x}=\left[\begin{array}{ll}\mathrm{x} 1 & \mathrm{x} 2\end{array}\right]$ adalah penjumlahan dari kuadrat kooordinat (Seperti pada Gambar 2, segitiga OPA atau segitiga OPB, $|\mathrm{OP}|^{2}$ adalah kuadrat dari panjang $\mathrm{x}$, adalah panjang titik $\mathrm{O}$ dan $\mathrm{P}$ ) dan 
jarak kuadrat diantara dua vector $\mathrm{x}=\left[\begin{array}{ll}\mathrm{x} 1 & \mathrm{x} 2\end{array}\right]$ dan $\mathrm{y}=[\mathrm{y} 1$ y2] adalah jumlah kuadrat dari perbedaan koordinatnya (seperti segitiga PQD (Gambar 2), $|\mathrm{PQ}|^{2}$ adalah kuadrat jarak antara titik $P$ dan $Q)$. Untuk menentukan jarak vector $\mathrm{x}$ dan $\mathrm{y}$ dapat digunakan notasi $\mathrm{d}_{\mathrm{x}, \mathrm{y}}$, sehingga menjadi persamaan ( Michael, 2008 ):

$$
d_{x, y}^{2}=(x 1-y 1)^{2}+(x 2-y 2)^{2}
$$

Sedangkan jarak $\mathrm{d}_{\mathrm{x}, \mathrm{y}}$ diperoleh dari persamaan (Michael, 2008 ):

$d_{x, y}=\sqrt{(x 1-y 1)^{2}+(x 2-y 2)^{2}}$

Jarak antara vector $\mathrm{x}=\left[\begin{array}{ll}\mathrm{x} 1 & \mathrm{x} 2\end{array}\right]$ dan vector nol $\mathrm{O}=\left[\begin{array}{ll}0 & 0\end{array}\right]$ adalah ( Michael, 2008 )

$$
d_{x_{0} 0}=\sqrt{x_{1}^{2}+x_{2}^{2}}
$$

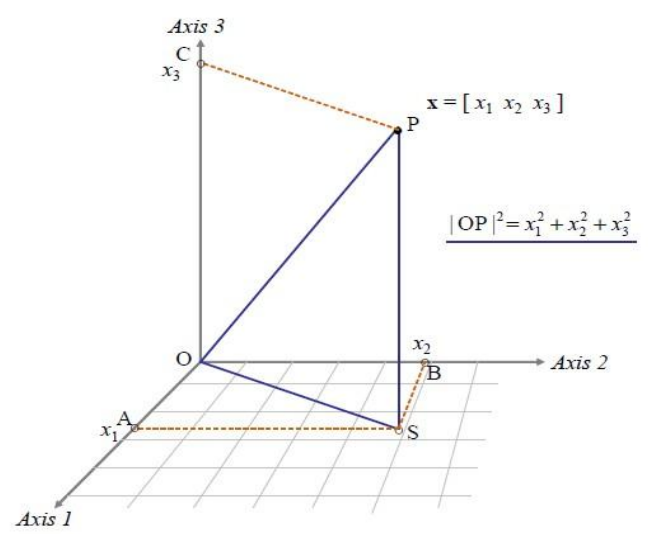

Gambar 3. Teorema Phytagoras untuk tiga dimensi ( Michael, 2008 )

Koordinat $\mathrm{x}$ dalam tiga dimensi dinyatakan dengan titik $\mathrm{x}$ $=\left[\begin{array}{lll}\mathrm{x} 1 & \mathrm{x} 2 & \mathrm{x} 3\end{array}\right]$ seperti pada Gambar 3. Tiga koordinat adalah titik $\mathrm{A}, \mathrm{B}$, dan $\mathrm{C}$ sepanjang sumbu, dan sudut $\mathrm{AOB}$, AOC, COB adalah $90^{\circ}$ seperti sudut OSP pada titik $\mathrm{S}$, dimana titik $\mathrm{P}$ diproyeksikan ke lantai (Gambar 3) dengan menggunakan teorema Phytagoras maka diperoleh :

$|\mathrm{OP}|^{2}=|\mathrm{OS}|^{2}+|\mathrm{PS}|^{2}($ karena sudut kanan pada titik $\mathrm{S})$

$|\mathrm{OS}|^{2}=|\mathrm{OA}|^{2}+|\mathrm{AS}|^{2}($ karena sudut kanan pada titik A). Dan juga $|\mathrm{OP}|^{2}=|\mathrm{OA}|^{2}+|\mathrm{AS}|^{2}+|\mathrm{PS}|^{2}$

Sehinga panjang kuadrat dari $\mathrm{x}$ dapat dinyatakan ( Michael, 2008):

$$
d_{x}=\sqrt{2+12^{2}+3^{2}}
$$

Untuk menghitung jarak antara x dan y adalah ( Michael, 2008 ):

$$
d_{x}=\sqrt{(x 1-y 1)^{2}+\left(x 2-y^{2}\right)^{2}+\left(x^{3}-y^{3}\right)^{2}}
$$

Bila jumlah dimensi j, dengan jumlah variable $\mathrm{j}$, maka jarak antara vector x dan y menjadi ( Michael, 2008 ) :

$d_{x, y}=\sqrt{\sum_{j-1}^{J}\left(x_{j}-y_{j}\right)^{2}}$

\section{K-Means Clustering}

Clustering didefinisikan sebagai teknik pencarian kemiripan pada suatu grup data. Setiap grup meruapakan satu cluster dan dapat pula didefinisikan sebagai suatu daerah dengan objek yang memiliki densitas lokal yang lebih tinggi dari daerah lain. Teknik clustering membagi data menjadi beberapa cluster yang spesifik dengan kriteria tertentu yaitu kriteria error yang merupakan kalkulasi jarak Euclidean antara pusat cluster dengan setiap titik data, dan tujuannya adalah meminimalkan error clustering atau jarak Euclidean. Error clustering berdasarkan pada pusat cluster $\mathrm{m}_{1}, \ldots, \mathrm{m}_{\mathrm{M}}$, dengan persamaan (A. Likas, et al., 2002) :

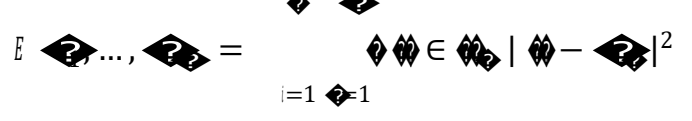

Patch Based Correlation

Pada penelitian ini, citra dibagi menjadi beberapa patch yang tidak saling tumpang tindih. Template citra dideskripsikan sebagai $t=[1$ menjadi beberapa $\mathrm{k}$ jumlah patch. Kemudian kemiripan antara template $t(i, j)$ dan citra tes $f(i, j)$ didefinisikan sebagai (G.Guo, et al, 2007 ) :

\section{$D ? ?={ }_{r=0}^{k}-2(? 2)$}

dimana adalah patch citra di dalam citra tes, sebagai template $t(i, j)$ yang bersesuaian pada posisi $(m, n)$ di dalam citra tes. Pada penelitian ini menggunakan 1norm pada eksperimen.

$D(t, f, m, n)$ adalah non negative. Nilai terkecil $D(t, f, m n, n)$ menunjukkan semakin mirip template citra dengan citra tes. Korelasi dalam citra adalah mencari fungsi objektif yang minimum dengan persamaan (G. Guo, et al, 2007 ) :

\section{(16)}

\section{HASIL}

Sebelum melakukan uji coba beberapa metode segmentasi warna, dilakukan terlebih dahulu analisis ruang warna yaitu dalam penelitian ini dilakukan analisis ruang warna RGB, HSV, dan CIE Lab. Analisis dilakukan dengan menerapkan metode segmentasi sederhana yaitu global thresholding dan memilih ruang warna yang memberikan hasil segmentasi yang optimal. Hasil segmentasi global thresholding pada ketiga ruang warna terlihat pada Gambar

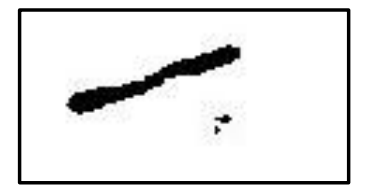


(a)

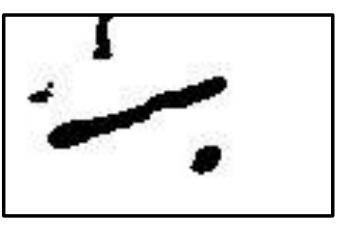

(c)

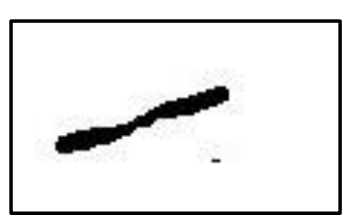

(d)
Gambar 4. (a) Gambar Asli, Hasil Segmentasi (a) Ruang RGB (b) Ruang HSV (c) Ruang CIE Lab

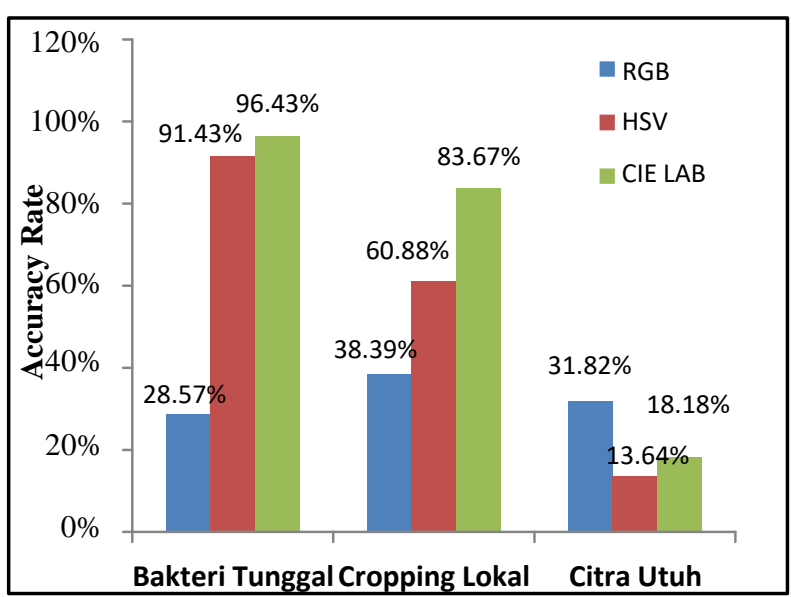

Gambar 5. Diagram Performansi Akurasi Metode Adaptive Global Thresholding

Dari diagram batang Gambar 5 dapat diketahui bahwa ruang warna CIE Lab memberikan hasil segmentasi bakteri TB dengan akurasi yang lebih tinggi dibandingkan ruang warna RGB dan HSV. Dan kondisi citra yang memberikan performansi akurasi yang paling baik adalah citra bakteri tunggal seperti ditunjukkan pada grafik Gambar 6.

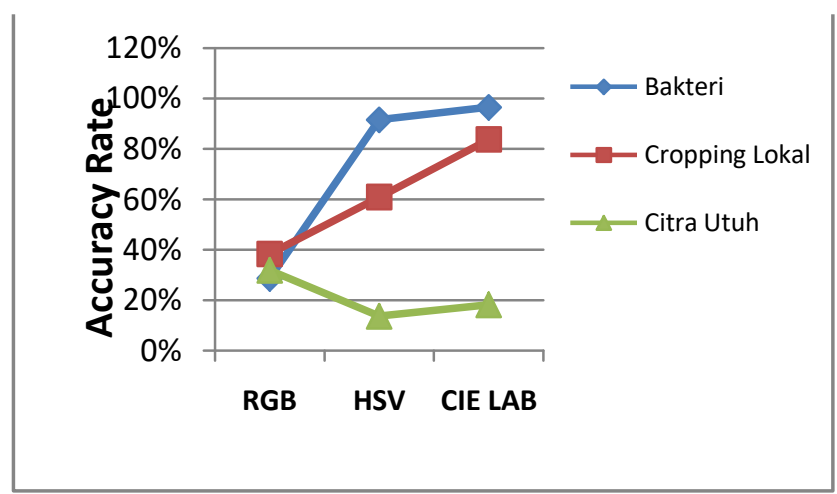

Gambar 6. Grafik Performansi Akurasi Metode Adaptive Global Thresholding

Berdasarkan hasil segmentasi warna dengan metode adaptive global thresholding, menunjukkan hasil yang baik pada kondisi pengolahan citra bakteri TB tunggal, hal inilah yang mendasari pengembangan penelitian ini untuk mengoptimalkan hasil segmentasi untuk citra utuh, dengan membagi citra utuh tersebut menjadi beberapa bagian sub citra kecil yang disebut patch citra, sehingga diharapkan diperoleh hasil segmentasi citra yang lebih akurat. Selain dengan metode adaptive global thresholding, juga diujicobakan metode K-Nearest Neighbors dan K-Means Clustering, dimana metode K-Nearest Neighbors memberikan hasil yang paling baik dengan akurasi $97,90 \%$ (seperti pada grafik Gambar 7), namun waktu komputasi yang dibutuhkan lama yaitu rata-rata sekitar 6 menit untuk aplikasi satu patch citra. Oleh karena itu, pada penelitian ini, mencoba menggunakan metode $K$-Means Clustering dengan patch yang dapat memberikan hasil yang cukup akurat.

Hasil segmentasi dengan menggunakan metode clustering berbasis patch dapat dilihat pada Gambar 8 sampai dengan Gambar 11.

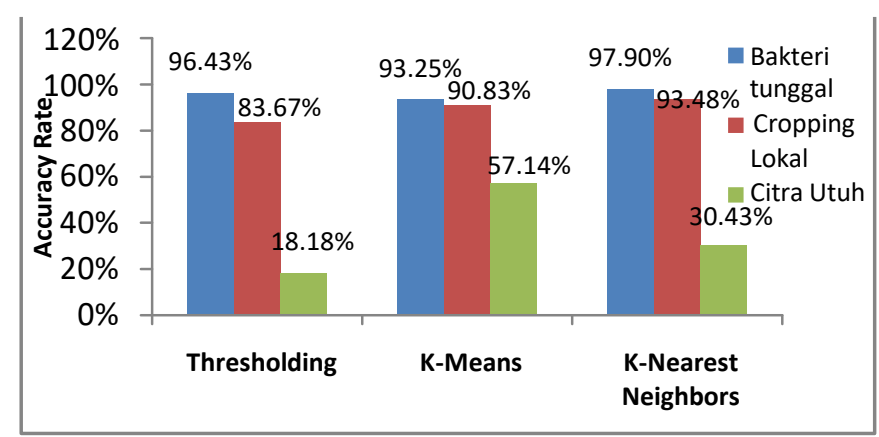

Gambar 7. Diagram Perbandingan Performansi Hasil Segmentasi

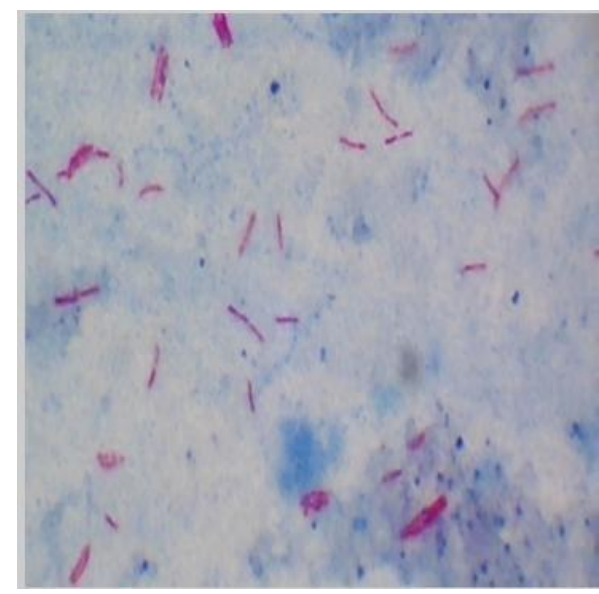

Gambar 8. Citra Digital Sputum Penyakit TBC 


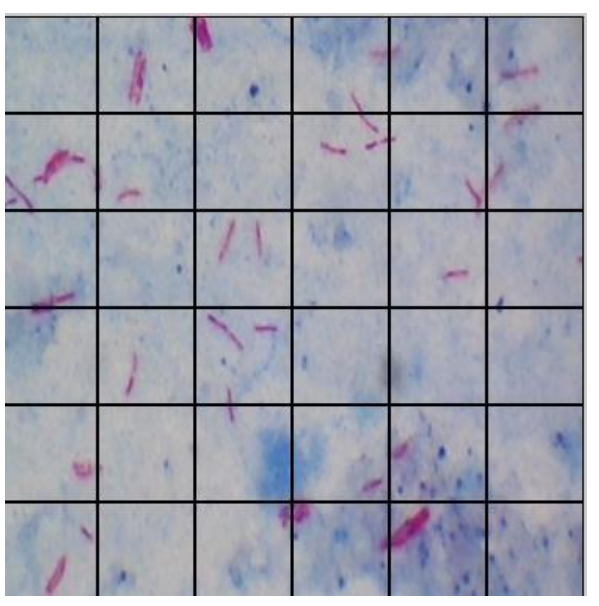

Gambar 9. Hasil Patch Citra

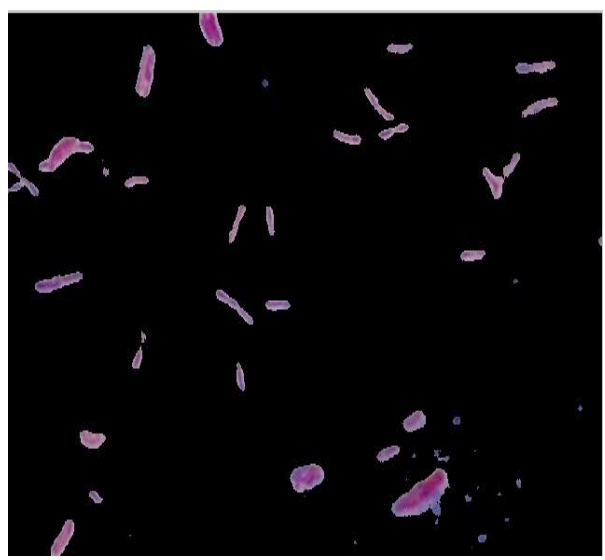

Gambar 10. Hasil Segmentasi Citra Metode K-Means Clustering tanpa Patch

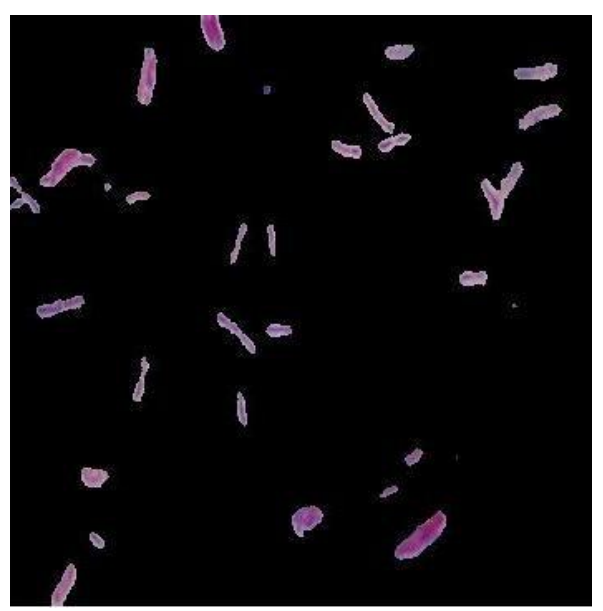

Gambar 11. Hasil Segmentasi Citra Metode K-Means Clustering dengan Patch

Dari hasil penerapan metode segmentasi K-Means Clustering berbasis patch pada citra berwarna sputum penyakit TBC, memberikan hasil segmentasi yang lebih baik dan lebih bersih dari citra background dibanding segmentasi hanya dengan menggunakan metode K-Means Clustering. Hasil segmentasi dengan didukung teknik patch, tidak lagi memerlukan pengolahan citra lebih lanjut untuk menghilangkan objek yang tidak diperlukan atau tidak diinginkan, sehingga hal ini akan mendukung keakurasian proses pengenalan pola bakteri TB dalam counting dan penentuan grade penyakit TBC. Hasil eksperimen pada penelitian menunjukkan laju keakurasian $100 \%$ dalam melakukan segmentasi citra yang diduga bakteri TB berdasarkan kriteria warna hasil pewarnaan Ziehl-Neelsen.

\section{Ucapan Terima Kasih}

Terima kasih untuk Laboratorium Teknik Biomedik Institut Teknologi Bandung, atas segala fasilitas yang telah diberikan kepada Penulis utama selama menempuh pendidikan S3 di ITB dan dukungannya pada panelitian ini.

\section{KESIMPULAN}

Dari hasil segmentasi warna dengan metode adaptive global thresholding memberikan hasil yang baik pada ruang warna CIE Lab, bila dibandingkan pada ruang warna RGB dan HSV.

Metode segmentasi citra berwarna yaitu clustering berbasis patch telah mampu menghasilkan citra tersegmentasi dengan keakurasian $100 \%$ lebih unggul dibandingkan metode K-Nearest Neighbors, sehingga dapat membantu proses identifikasi bakteri TB yang lebih akurat lagi pada penerapan sistem diagnosis penyakit TBC yang terkomputerisasi.

\section{DAFTAR PUSTAKA}

Departemen Kesehatan Republik Indonesia, 2007, "Pedoman Nasional Penanggulangan Tuberkulosis".

G. Guo, C.R. Dyer, "Patch-based Image Correlation with "Rapid Filtering, 2007, IEEE Xplore

Hunter Lab, 2008“Measure Color", www.hunterlab.com.

M. Forero, F. Sroubek, and M.Desco, august 2006 , "Automatic identification of nycobacterium tuberculosis by Gaussian mixture models", Journal of microscopy, vol.223 no.2, pp.120-132.

M.K.Osman, M.Y.Mashor, Z.Saad, H.Jaafar, 2010, "Segmentation of Tuberculosis Bacilli in Ziehl-Neelsen Stained Tissue Images based on K-Mean Clustering Procedure", IEEE Xplore.

M.K Osman, M.Y. Mashor, H. Jaafar, 2011, "Combining Thresholding and Clustering Techniques for Mycobacterium Tuberculosis Segmentation in Tissue Sections", Australian Journal of Basic and Applied Sciences.

Michael, 2008, "Measures of distance between samples:Euclidean",http://www.econ.upf.edu/ micha el/stanford/maeb4.pdf

R. Khutlang, S.Krishnan, R. Dendere, A. Whitelaw, K. Veropoulos, G. Learmonth, T.S. douglNIas, 2009, 
Jurnal Biosains Pascasarjana Vol. 17 (2015) pp

(C) (2015) Program Pascasarjana Universitas Airlangga, Indonesia

"Classification of Mycobacterium Tuberculosis in

Images of ZN-Stained Sputum Smears", IEEE Xplore.

R.C. Gonzales, Richard E.Wood,Steven L.Eddins, 2008, Digital Image Processing Third Edition, Pearsonson Prentice Hall

S.W. Harahap, 22 Mei 2012, Jumlah Penderita TBC di Indonesia Peringkat 4 di Dunia, Kompasiana, www.kompas.com.

V. Makkapati, R. Agrawal, R. Acharya (2009, August), "Segmentation and Classification of Tuberculosis Bacilli from ZN-stained sputum /smear Images", in IEEE Conference on Automation Science and Engineering, Bangalore - India.

W.K. Pratt, 2007, "Digital Image Processing", WileyInterscience, A John Wiley \& Sons, Inc. 